\title{
Production of a Phytoalexin, Sakuranetin, in the Sekiguchi Lesion on Rice cv. Sekiguchi-asahi*
}

\author{
Sakae ArAsE**, Yohko YoshiUrA**,***, Yoshihisa OzoE**, Yuichi HondA** \\ and Mikio NOZU**
}

Key words : phytoalexin, Sekiguchi lesion, rice cv. Sekiguchi-asahi.

Rice cv. Sekiguchi-asahi, which showed unique response to the infection of Magnaporthe grisea (Hebert) Barr (imperfect stage, Pyricularia oryzae Cavara) or Bipolaris oryzae (Breda de Haan) Shoemaker or to chemical treatments, was found as a mutant of $\mathrm{cv}$. Asahi". This unique lesion was named "Sekiguchi lesion"6). Recently, a new mutant rice formed the Sekiguchi lesion was found from cv. Himenomochis). In previous reports ${ }^{1,4,6)}$, it was demonstrated that the compatible race of $M$. grisea induced typical blast lesions besides the Sekiguchi lesions and that the incompatible races induced only the Sekiguchi lesions on cvs. Sekiguchi-asahi and Sekiguchi-himenomochi. Although size of the Sekiguchi lesions was larger than that of blast lesions, no sporulation of both the compatible and incompatible races of $M$. grisea was observed on the Sekiguchi lesion. Further, Bipolaris spp. were more frequently isolated as compared with $M$. grisea from naturally-formed Sekiguchi lesions ${ }^{8)}$. These observations suggested that the anti-fungal substances to $M$. grisea were produced in the Sekiguchi lesions. In this paper, we report a phytoalexin, Sakuranetin, is produced in naturally-formed Sekiguchi lesions on rice cv. Sekiguchi-asahi.

Naturally-formed Sekiguchi lesions ( $1 \mathrm{~g}$ ) on leaves of rice cv. Sekiguchi-asahi were collected and chopped, and then immersed into $80 \%$ methanol at room temperature under dark. After 7 days, methanol-soluble fraction was evaporated at $35^{\circ} \mathrm{C}$ under reduced pressure. Aqueous layer was extracted with benzene, and the extract was concentrated. The anti-fungal activity of each fraction obtained from the benzene extract was determined by the inhibition test in spore germination of $M$. grisea (isolate Naga 69-150). Benzene extracts were subjected to silica gel column chromatography (Wakogel C200) and eluted with chloroform and methanol, increasing the concentration of latter stepwise. Active components were eluted by chloroform. Chloroform-eluted fraction was subjected to Sephadex LH-20 column chromatogra- phy (column size; $1.0 \times 26 \mathrm{~cm}$ ) using methanol as the solvent. The elute was fractionated every $2 \mathrm{ml}$ to tubes. The fractions (Tube No. 14-17) having anti-fungal activity were subjected to thin layer chromatography (TLC) (Merck Kieselgel $60 \quad \mathrm{~F}_{254}, 20 \times 20 \mathrm{~cm}$ ) developed with benzene-ethyl acetate $10: 1(\mathrm{v} / \mathrm{v})$. After development, the TLC plates were divided into ten equal sections, and silica gel of each section was extracted with methanol. Anti-fungal activity was found at $R f 0.2$ to 0.3 . Particularly, inhibition activity of the zone which showed red in the color of fluorescence under $365 \mathrm{~nm}$ UV light was higher than that of the other zones between $R f 0.2$ and 0.3 . Red area between $R f 0.2$ and 0.3 on the developed TLC was scraped off and extracted with methanol. UV spectrum of an anti-fungal substance was obtained with a Hitachi Ubest-35 UV/VIS Spectrophotometer. The absorption range of methanol extract in $99 \%$ methanol was limited to nearly UV region under $400 \mathrm{~nm}$, and it had peak at near $283 \mathrm{~nm}$. The methanol extract was subjected to the HPLC (Hitachi L-6000, Develosil ODS-5, column size ; $4.6 \times 250 \mathrm{~mm}$ ) and eluted with $99.7 \%$ methanol monitoring at $283 \mathrm{~nm}$. Distinct single peak of an antifungal substance appeared at Rt $2.9 \mathrm{~min}$. This result indicated that the sample was highly purified. Therefore, this sample was analyzed by electron impact mass (EIMS) spectrometry and proton nuclear magnetic resonance (1H-NMR) spectrometry. MS and $1 \mathrm{H}-\mathrm{NMR}$ spectra of the anti-fungal substance were obtained with a Hitachi M-80B mass spectrometer, using a direct inlet system and with a JEOL JNM-GX 270 FT NMR Spectrometer, respectively. The MS spectrum of this sample showed a distinct molecular ion peak at $m / z 286$ (Fig. 1). Further, the NMR spectrum (Fig. 2) was in close agreement with that in the literature ${ }^{2)}$. From the results of instrumental analyses, we identified it as sakuranetin (5,4'-dihydroxy-7-methoxyflavanone) which was previously isolated from bark of Prunus yedoensis Matsum. by Asahina ${ }^{3)}$. Sakuranetin was not detected from healthy rice leaves. So, it is a phytoalexin of rice plant.

* This study is part 11 in series, "Studies on Host-Selective Infection Mechanism of Magnaporthe grisea (Hebert) Barr", and was supported in part by Grant-in-aid (No. 07660058) to S. Arase from the Ministry of Education, Science and Culture of Japan.

** Faculty of Life and Environmental Science, Shimane University, Matsue 690, Japan 島根大学生物資源科学部

*** Present address: Nippon Shinyaku Co., Ltd., Minami-ku, Kyoto 601, Japan＼cjkstart現在：日本新薬 K.K. 中央研究所 


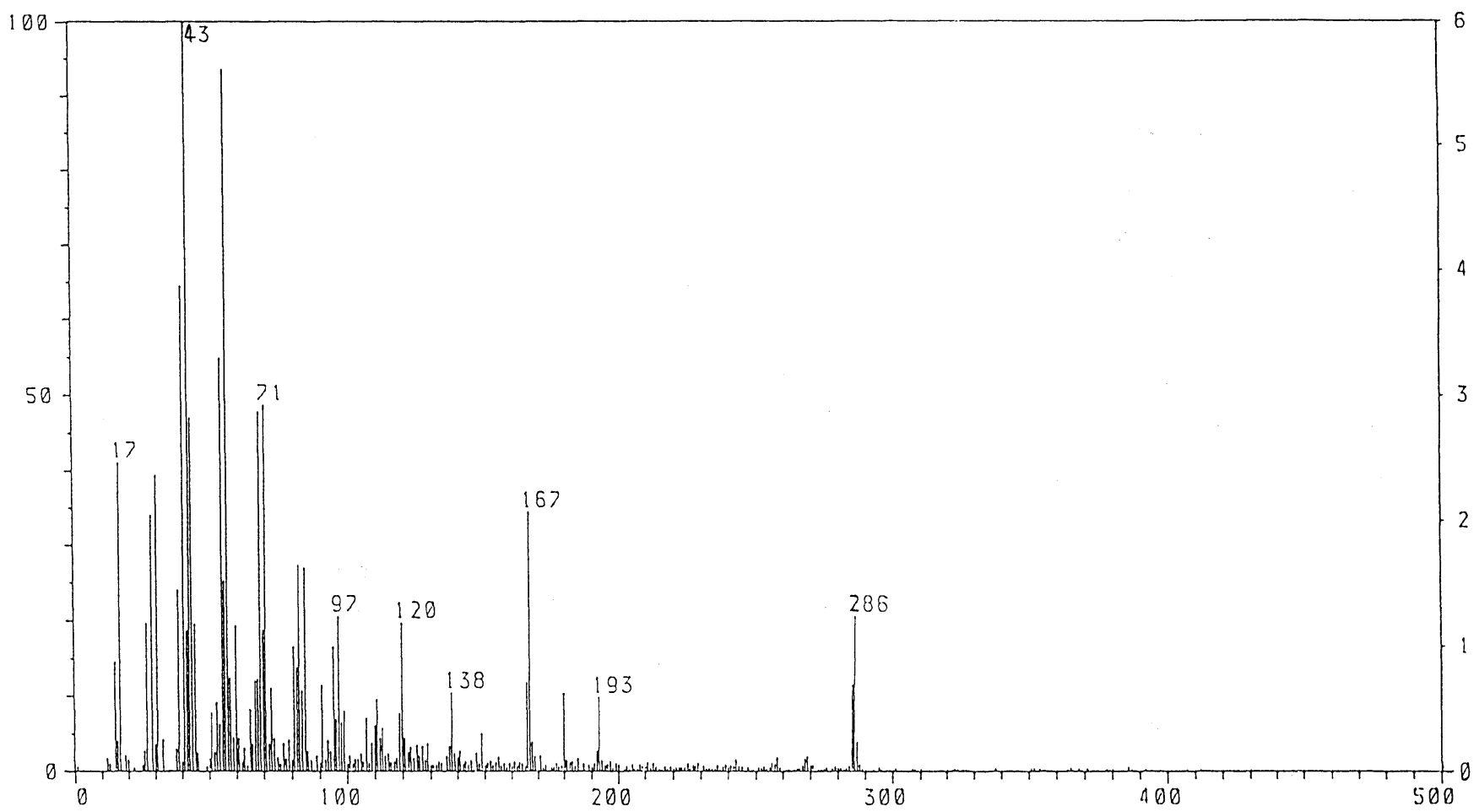

Fig. 1. EIMS Spectrum of the sample.

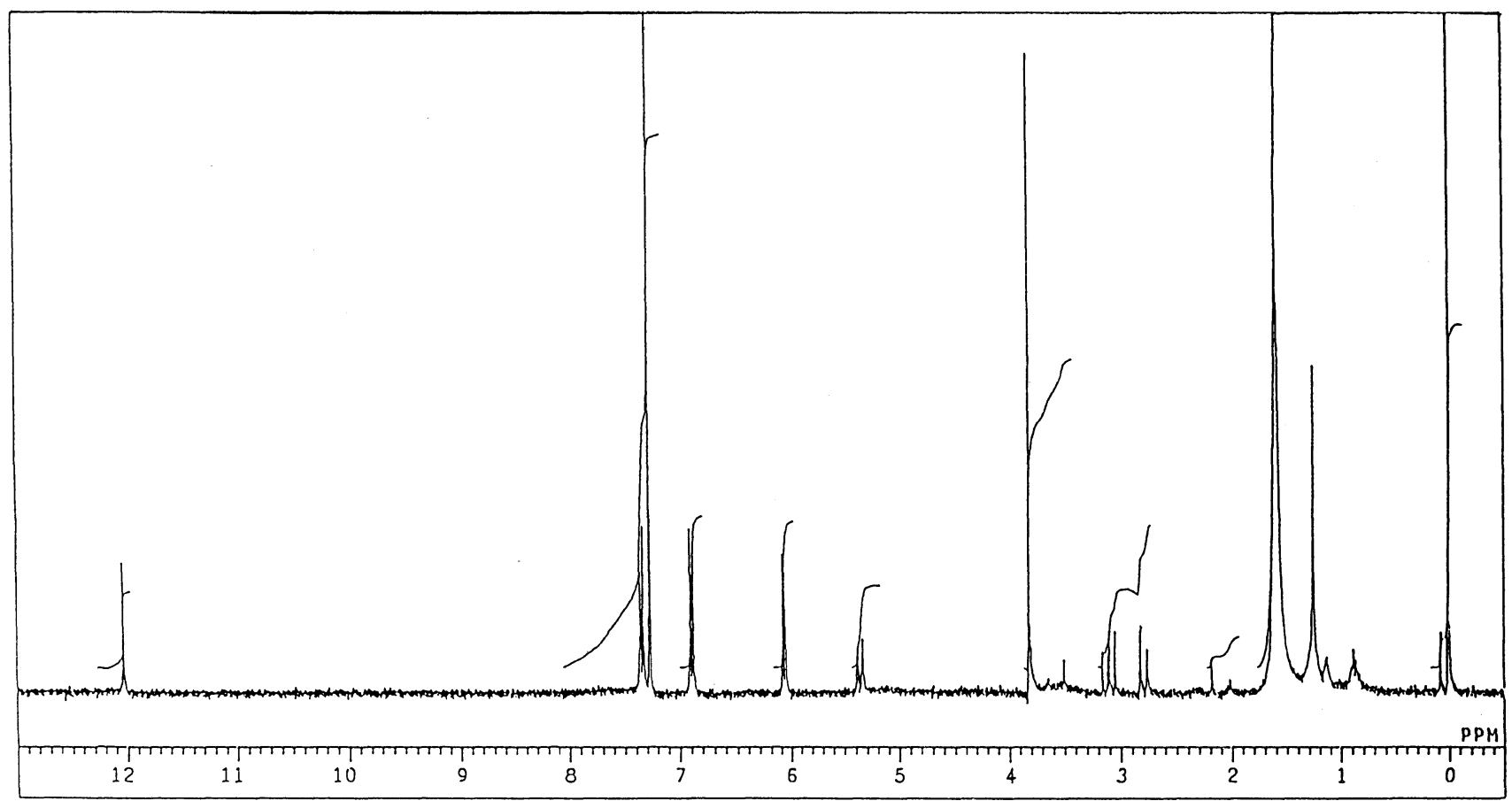

Fig. 2. 1H-NMR Spectrum of the sample dissolved in $\mathrm{CDCl}_{3}$.

Recently, Kodama et $a l^{7)}$ isolated this compound from UV-irradiated and incompatible $M$. grisea-infected rice leaves. As mentioned above, formation of large Sekiguchi lesions in the Sekiguchi rice lines was induced by the incompatible races of $M$. grisea. Our result in this study suggests that a phytoalexin, sakuranetin, is playing the important role for the resistance expression of mutant rice plants, such as cvs. Sekiguchi-asahi and Sekiguchihimenomochi, infected with the incompatible races of
M. grisea.

\section{Literature cited}

1. Arase, S., Kano, M., Kondo, K., Nozu, M., Tanaka, E. and Nishimura, S. (1988). Studies on host-selective infection mechanism of Pyricularia oryzae Cavara (1) Usefulness of cv. Sekiguchi-asahi as a test plant for detection of disease determinants. Bull. Fac. Agric. 
Shimane Univ. 22 : 176-183.

2. Asahi Research Center ed. (1985). Handbook of Proton-NMR Spectra and Data, Vol. 5, Academic Press Japan. Inc., Tokyo, p. 170.

3. Asahina, Y. (1908). Ueber das Sakuranin, ein neues Glykoid der Rinde von Prunus Pseudo-Cerasus Lindl. var. Sieboldi Maxim. Arch. Pharm. 246 : 259-272.

4. Fujita, K., Arase, S., Honda, Y., Nozu, M., Kadowaki, Y. and Isota, J. (1994). Response of a mutant from rice cv. Himenomochi to inoculation of Pyricularia oryzae. Ann. Phytopathol. Soc. Jpn. 60 : 329 (Abstr.) (in Japanese).

5. Isota, J., Kadowaki, Y. and Arase, S. (1996). Spontaneous occurrence of the Sekiguchi lesion on rice $\mathrm{cv}$. Himenomochi. Ann. Phytopathol. Soc. Jpn. 62 : 167-169.

6. Kiyosawa, S. (1970). Inheritance of a particular sensitivity of rice variety Sekiguchi Asahi, to pathogens and chemicals and linkage relationships with blast resistance gene. Bull. Natl. Inst. Agric. Sci., Ser. D 21 : 61-72.

7. Kodama, O., Miyakawa, J., Akatsuka, T. and Kiyosawa, S. (1992). Sakuranetin, a fravanone phytoalexin from ultraviolet-irradiated rice leaves. Phytochemistry 31 : 3807-3809.

8. Kurihisa, H. and Arase, S. (1986). Formation of the
"Sekiguchi lesion" on cv. Sekiguchi-asahi and its causal fungi. Bull. Assoc. Plant Prot. Shimane 11: 32-35 (in Japanese).

9. Sekiguchi, Y. and Furuta, T. (1965). On a rice mutant showing particular reaction to some spotting disease. Preliminary report. Ann. Phytopathol. Soc. Jpn. 30 : 7172 (Abstr.) (in Japanese).

\section{和 文 摘 要}

荒瀬 栄・吉浦洋子・尾添嘉久・本田雄一・野津幹雄：イネ品 種関口朝日に形成された関口病斑におけるファイトアレキシ ン, サクラネチンの生成

イネいもち病菌胞子の発芽阻害を指標にして関口病斑中に存 在する抗菌物質の検出を試みた。関口病斑の $80 \%$ メタノール抽 出物をベンゼン抽出し, これをシリカゲルおよび Sephadex LH-20 のカラムクロマトグラフィーにより，抗菌物質を部分純 化した。これを薄層クロマトグラフィー (ベンゼン：酢酸エチ ル，10:1, v/v）により純化後, UV, EIMS および NMR によ り機器分析した。その結果, 関口病斑中の抗菌物質は, サクラの 樹皮から単離された既知のサクラネチンと同定された。

(Received September 11, 1995; Accepted February 7, 1996) 